\title{
Note concerning the Translation
}

All translations from unpublished archival sources are my own, unless otherwise noted. I have sought to provide the most direct and literal translations possible, but because it is difficult to capture the vocabulary and rhythms of these depositions and judicial proceedings in English, I have included the original in the main text. I have modernised spelling and punctuation, and used italics when the handwriting or the condition of the file made it difficult to decipher.

I have used Edith Grossman's translation of Don Quixote; as per custom, each quote is identified by the Part (I or II) and chapter. (Don Quixote, a new translation by Edith Grossman. Introduction by Harold Bloom. Translation copyright (c) 2003 by Edith Grossman; introduction copyright $\odot 2003$ by Harold Bloom Reprinted by permission of HaperCollins Publishers.) Translations of all secondary sources are my own, unless otherwise noted. 